Maciej Paszyn

Łódź

\title{
BIZNESOWE RELACJE KONCERNÓW ENERGETYCZNYCH Z AUSTRII I NIEMIEC W OKRESIE KRYZYSU FINANSOWEGO LAT 2008-2013
}

Celem niniejszego artykułu jest przedstawienie współpracy rynku energetycznym firm austriackich i niemieckich, pokazanie ich wzajemnych relacji, inwestycji i wspólnych przedsięwzięć biznesowych w latach 2008-2013.

Opisywane $\mathrm{w}$ artykule przypadki aktywności biznesowej dotyczą głównie wielkich firm energetycznych dominujących na małym, aczkolwiek zamożnym rynku austriackim, inwestujących, także, na znacznie większym rynku niemieckim. Cechą charakterystyczną austriackich firm paliwowych jest znaczący udział państwa w ich akcjonariacie. $W$ ten sposób władze państwa mają wpływ na strategie działania firm, mogąc realizować długofalowe cele gospodarcze, a niekiedy i polityczne.

Gospodarka Austrii poprzez silne więzi z gospodarką unijną i światową jest zależna od wahań zewnętrznej koniunktury gospodarczej. Słaba koniunktura gospodarcza na świecie i w Niemczech - największym partnerze handlowym Austrii oraz rosnący kurs euro do dolara miały wpływ na osłabienie dynamiki eksportu towarów austriackich. Zwiększyło także koszty importowanych do republiki paliw. W Austrii prawie 70\% energii elektrycznej dostarczają elektrownie wodne. W kraju nie ma elektrowni atomowych. Produkcja energii elektrycznej na 1 mieszkańca wynosi ponad $6600 \mathrm{kWh}$ rocznie ${ }^{1}$. Rząd austriacki zliberalizował w $2001 \mathrm{r}$. w 100\% rynek energii elektrycznej, a w 2002 r. rynek gazu ziemnego. Na zliberalizowanym austriackim rynku energetycznym coraz większą rolę jako

${ }^{1}$ Energy Policies of IEA Countries. Austria Rewiew, Internationa Energy Agency, Paris 2009, s 11. Patrz też:Austrian Energy Agency, Energy Efficiency Policies and Measures in Austria, Vienna 2009. 
przyszła gałąź przemysłu odgrywają odnawialne nośniki energii. Udział odnawialnych nośników energii w całkowitym zużyciu energetycznym Austrii wzrastał szybko od połowy lat 70. i stanowi teraz ponad 23\% całkowitego zużycia. Najważniejszym odnawialnym źródłem energii jest energia wodna (ponad $11 \%$ całkowitego zużycia), a na drugim miejscu (około $11 \%$ ) paliwa biogeniczne (przede wszystkim biomasa) ${ }^{2}$. Austria plasuje się na trzecim miejscu w UE (po Szwecji i Finlandii) pod względem udziału odnawialnych źródeł energii w całkowitym zużyciu energii. Pod koniec 2009 roku działało w Austrii 164 elektrowni wiatrowych o mocy 139,3 MW. Elektrownie te wyprodukowały w roku 2002 około 250 GWh prądu, co pokryło zapotrzebowanie około 70.000 gospodarstw domowych ${ }^{3}$. Pod względem wykorzystania energii słonecznej do ocieplania wody Austria zajmuje drugie miejsce w UE (po Grecji). Udział termicznego wykorzystania energii słonecznej $\mathrm{w}$ całkowitym zużyciu energii nie przekracza jednak $1 \%$. Udział natomiast biomasy w całkowitym zużyciu energii wynosi już około $10 \%$, a prawie pół miliona gospodarstw domowych wykorzystuje biomasę jako materiał grzewczy. Jednymi z coraz bardziej popularnych źródeł energii odnawialnej są także biogaz i biopaliwa. Warto tutaj także krótko wspomnieć o ciekawym źródle energii cieplnej jakimi są termy. Nie odgrywają one wprawdzie wielkiego znaczenia gospodarczego w Austrii (potencjał to około $2000 \mathrm{MW}$ energii cieplnej i $7 \mathrm{MW}$ prądu), ale stanowią ciekawą odmianę i pokazują w jaki sposób podchodzi się w Austrii do nawet najmniejszych możliwości zdobycia energii.

Latem 2009 roku na energetycznym szczycie kanclerz Austrii Werner Faymann powiedział, że Austriacy nie chcą już więcej prądu z atomu ${ }^{4}$. Zakaz sprzedaży i importu atomowego prądu skutkowałby także koniecznością powołania specjalnych struktur, urzędów, które zajmowałyby się śledzeniem i certyfikowaniem źródeł pochodzenia prądu ${ }^{5}$.

2 Energy policies..., s. 14.

${ }^{3}$ Ibidem, s. 30.

${ }^{4}$ Greenpeace oraz organizacja Global 2000 zleciły wykonanie analizy prawnej. Została ona przeprowadzona przez niemiecką sepcjalistkę $\mathrm{w}$ dziedzinie prawa ochrony środowiska dr Michele John i austriackiego specjalistę w zakresie austriackiego prawa energetycznego dr Reinharda Schanda. Z opracowania wynika, że zakaz importu energii jądrowej nie jest sprzeczny z prawem Unii Europejskiej. Jego autorzy stwierdzili, że zgodnie z prawem europejskim i zasadami Światowej Organizacji Handlu (WTO) swoboda przepływu towarów i usług może zostać ograniczona z uwagi na ryzyko zagrożenia zdrowia lub ochronę środowiska. Atomowe.kei.pl.

${ }_{5}^{5}$ Antyatomowa inicjatywa Austrii ma na celu również zniechęcenie państw sąsiednich, szczególnie Czech, do budowy nowych reaktorów, Przeforsowanie zamiaru powinno zniechęcić Czechów do inwestycji w atom z powodów także ekonomicznych, bowiem Praga poprzez budowę elektrowni atomowych liczy na eksport energii i zyski z tego tytułu. 
Jednym z głównych celów polityki energetycznej rządu austriackiego jest stworzenie przyjaznego dla środowiska systemu energetycznego. Główne cele strategii polityki energetycznej Austrii to zwiększanie wydajności energetycznej i wspieranie odnawialnych źródeł energii. Zmiany które w najbliższych latach czekają energetykę austriacką są bardziej daleko idące niż te proponowane przez UE. O ile Komisja Europejska proponuje do 2020 zmiany polegające na redukcji gazów cieplarnianych o 20\% i także 20\% udział energii odnawialnej w ogólnej produkcji energii, to austriackie założenia wynoszą 16 procentową redukcję emisji i 34\% udział energii odnawialnej Austria należy do pięciu państw UE, które do 2020 mają zwiększyć udział energii odnawialnej w ogólnej sumie do $25 \%$. Chodzi także o nową strategię energetyczną i ochrony środowiska. W lutym 2007 rząd austriacki opublikował nową strategię zmian klimatu zakładającą coroczne obniżenie emisji o 9 milionów ton CO2 w latach 2008-2012. Ta nowa strategia zaakceptowana przez rząd w marcu 2007 zakładała zwiększenie nakładów na energię odnawialną ${ }^{6}$.

$\mathrm{W}$ tym samym czasie $\mathrm{w}$ maju 2011 roku, kilka miesięcy po awarii elektrowni atomowej w Fukushimie, rozpoczęła się transformacja energetyczna RFN przedstawiana jest jako decyzja ostateczna, a ze względu na narzucone tempo zmian stanowi nową jakość w strategii energetycznej Niemiec. Głównymi jej założeniami są: rezygnacja z energii jądrowej do 2022 roku, rozwój odnawialnych źródeł energii (OZE), rozbudowa sieci przesyłowych, budowa nowych elektrowni konwencjonalnych i wzrost efektywności energetycznej. Strategia ma się opierać głównie na rozwoju odnawialnych źródeł energii. Zgodnie z nowelizacją ustawy o OZE, udział energii odnawialnej w produkcji prądu ma systematycznie wzrastać - z obecnych ok. $20 \%$ do ok. $38 \%$ w 2020 roku. W 2030 roku ma on już wynieść około $50 \%$, w 2040 roku - 65\%, a w 2050 - aż $80 \%$. Jak podkreślają specjaliści rynku paliwowego i publicyści zajmujący się tymi zmiana$\mathrm{mi}$, konsekwencje Energiewende nie ograniczą się do sfery zaopatrzenia $\mathrm{w}$ energię. W długim okresie spodziewać się można zmian w funkcjonowaniu gospodarki, niemieckiego społeczeństwa i państwa. Energiewende może okazać się początkiem "trzeciej rewolucji przemysłowej” w kierun$\mathrm{ku}$ „zielonej gospodarki“.

Przemiany do jakich doszło w wyniku decyzji politycznych dotyczących zmian w energetyce $\mathrm{w}$ oczywisty sposób mają wpływ na działania firm paliwowych, zarówno w Austrii, jak i w Niemczech.

${ }^{6}$ Energy Policies and Measures in Austria, s. 63 -65.

7 A. Kwiatkowska-Dróżdż, Niemiecka transformacja energetyczna: trudne początki, Raport OSW 12.2012. 
Największym producentem energii w Austrii jest Verbund AG, znany jako Verbundgesellschaft lub Österreichische Elektrizitätswirtschafts-AG. Verbund produkuje ponad 40 procent wyprodukowanej w tym kraju energii, z czego 90 procent energii wodnej. Firma Verbund jest notowana na Wiedeńskiej GPW i należy do tzw blue chipów na tym parkiecie. Ta istniejąca od 1947 roku firma jest głównym dostawcą prądu w Republice. W umocnieniu pozycji nie przeszkodziły bynajmniej dwukrotne nacjonalizacje firmy dokonane przez władze w 1956 i 1987. Od tej pory państwo ma głos decydujący w zarządzaniu koncernem. Co prawda, od 1988 roku 49 procent akcji firmy jest notowanych na wiedeńskiej giełdzie, to jednak państwo ma głos decydujący. W latach dziewięćdziesiątych austriacki przemysł energetyczny po raz kolejny uległ zmianom organizacyjnym. Lokalne firmy energetyczne jak TIWAG (operujący w Tyrolu) i EVN (Dolna Austria), zostały dokapitalizowane na giełdzie lub wchłonięte właśnie przez Verbund. Celem tych działań konsolidacyjnych było wzmocnienie narodowego operatora, znajdującego się w rękach państwa. które we wszystkich tych podmiotach posiadało ponad 25\% akcji. Ponad $90 \%$ energii wytwarzanej przez Verbund jest wynikiem funkcjonowania rozwiniętych elektrowni wodnych w Austrii. Verbund posiada 88 elektrowni wodnych umiejscowionych w górskich regionach Tyrolu, Karyntii i Styrii, oraz na Dunaju i innych rzekach. Moce energetyczne Verbundu związane z produkcją energii wodnej oceniane są na 6,600 MW; a produkcja energii na 24.8 miliardów kWh. Ponadto Verbund jest zaangażowany w produkcję energii cieplnej będąc jednym z jej największych dostawców w Austrii. Roczna produkcja wynosi $900 \mathrm{mln}$ kWh Elektrownie należące do koncernu: Dürnrohr, Mellach i Neudorf-Werndorf II mają moc 815 megawatów.

W 2009 Verbund kupił 13 elektrowni budowanych na rzece Inn w Bawarii, Łączna wydajność nowych elektrowni ma wynieść 312 megawaty, a produkcja prądu 1.85 miliardów kWh. Kupno hydroelektrowni wybudowanych wspólnie z koncernem EON, ma być krokiem do stania się największym producentem energii wodnej $\mathrm{w}$ Europie $^{8}$. W dniu 03.12.2012, Wiedniu ogłoszono, że Verbund, jako „wiodący producent energii elektrycznej w Austrii, w dalszym ciągu zamierza umacniać swoją pozycję jako jednego z najważniejszych w Europie producentów energii elektrycznej z energii wodnej". Dla tego Verbund zdecydował się na kupno akcji od E.ON-u, ponadto kupił udziały w budowanych kolejnych ośmiu elektrowniach wodnych na rzekach Inn i Dunaj. Działania te podnieść miały średnią roczną produkcję o około 2 miliardy kilowatogodzin $(\mathrm{kWh})$. To wartość równa rocznemu zużyciu energii elektrycznej około

8 Verbund kupit elektrownie od E.ON, Rzeczpospolita, 6.09.2009, 
600.000 gospodarstw domowych. Przejęte przez austriacki koncern elektrownie wodne to: Ering, Egglfing i Nussdorf o łącznej produkcji $592 \mathrm{mln}$ kWh. Ponadto Verbund obejmie 50\% udziałów w Österreich - Bayerische Kraftwerke AG (OBK) posiadających elektrownie Oberaudorf - Ebbs, Simbach - Braunau, Schärding - Neuhaus, Passau - Ingling produkujących $994 \mathrm{mln}$ kWh. W ramach transakcji, Verbund wykupi także 20,28\% produkcji elektrowni Zemm-Ziller (około $237 \mathrm{mln} \mathrm{kWh}$ ). Jest to wzrost o 60\% sumy energii elektrycznej, która miała być przedmiotem obrotu pomiędzy firmami, uzgodnionych z E.ON w 2009 roku.Ponadto Verbund również zakupił od EON 50\% udziałów w elektrowniach wodnych Freilassing (potencjał produkcyjny $18 \mathrm{MW}$ ), Tittmoning (ok. $18 \mathrm{MW}$ ) i Riedl. Po sfinalizowaniu nabycia akcji, osiem elektrowni stanąć się ma w całości własnością Verbund ${ }^{9}$. Oprócz tego, Verbund podjął się przekazania grupie EON ponad 200,000,000 kWh, pochodzących z hydroelektrowni Zemm- Ziller $^{10}$. W zamian E.ON, jeden $z$ największych światowych dostawców energii, będzie nabywać akcje Verbund w tureckiej EnerjiSA ${ }^{11}$. Po zakończeniu transakcji niemiecki koncern ma posiadać 50\% akcji. Transakcja ta wynikała z faktu, ze Verbund koncentruje się na realizacji jej strategicznych priorytetów, związanych z obecnością na rynkach w Austrii i Niemczech. Ponadto firma ta doszła do wniosku, ze należy wzmocnić swoją obecność na najważniejszych dla niej rynkach - austriackim i niemieckim. Jak stwierdził prezes Wolfgang Anzengruber: „Chcemy skupić się na na rynkach w Austrii i Niemczech. Dlatego podejmujemy możliwość rozszerzenia naszej produkcji energii wodnej w Niemczech i chcemy zyskać większą kontrolę nad istniejącymi inwestycjami. Transakcja ta umacnia naszą pozycję jako jednego z wiodących producentów elektrowni wodnych $w$ Europie. Po transakcji, elektrownie będą w całości własnością Verbundu. W przyszłości, te elektrownie pozwolić mają Verbundowi wygenerować całkowitą średnio 3,9 mld kWh energii elektrycznej z elektrowni wodnych w roku"12.

Nabycie elektrowni wodnych w Niemczech dodatkowo wspomaga sprzedaż Verbundu i działalność handlową w jego najważniejszym rynku międzynarodowym. W 2011 Verbund sprzedał około 60\% wyprodukowanej prze siebie energii elektrycznej na rynkach międzynarodowych, głównie rynku niemieckim. W 2011 roku z około 28 mld kWh energii, przeznaczonych na eksport, około, 75\%, została sprzedana w Niemczech.

9 VERBUND and E.ON successfully conclude asset swap.www.verbund.com/at, 4.12.2012.

${ }^{10}$ Ibidem.

11 T. Andresen, E. Ersoy, EON Expands in Turkey Through Asset Swap Deal With Verbund, Bloomberg, 4.12.2012.

12 Ibidem. 
Zwiększone inwestycje Verbundu, na terenie Niemiec spowodowały, że inna austriacka firma energetyczna EVN zapowiedziała, że jej wynik finansowy spadł o 30,9 procent w pierwszej połowie 2012, w wyniku niższych dochodów z inwestycji, takich jak dywidendy wypłaconej przez Verbund AG. Przypomnieć należy, że EVN wraz z Wiener Stadtwerke posiada 25 - procentowy udział w Verbund. Zysk netto 2011 EVN wyniósł 207 milionów euro, EBIT-a 187,3, przy obrotach rzędu 2,75 mld euro ${ }^{13}$.

Największą firmą paliwową Austrii jest OMV („Österreichische Mineralölverwaltung, ÖMV), Firma ta zdominowała rynek paliwowy republiki. Będąc wiodącym importerem i dystrybutorem ropy i gazu osiągnęła znaczącą pozycję na rynku gospodarczym kraju. 30 tysięcy pracowników wypracowało 34 miliardy euro. Poza importem zajmuje się też eksploatacją lokalnych złóż. W 2010, OMV wydobyło 840 tysięcy ton ropy i 1,5 miliarda m sześciennych gazu. W ten sposób dostarczając odpowiednio $87 \%$ i $88 \%$ austriackiego lokalnego wydobycia tych paliw. W ostatniej dekadzie widoczna jest ekspansywna polityka firmy. OMV kupił 10\% akcji węgierskiej firmy MOL stając się jej największym instytucjonalnym akcjonariuszem $^{14}$. W roku 2007 OMV powiększył swój udział w węgierskim MOL do $20.2 \%$. Wobec sprzeciwu Komisji Europejskiej w 2009, OMV zmuszony był sprzedać część akcji. Głównymi akcjonariuszami OMV są: 31,5\% Österreichische Industrieholding AG - fundusz inwestycyjny Republiki, 24,9\% International Petroleum Investment Company, fundusz inwestycyjny założony w 1984 w Abu Dabi. Ponad 43\% akcji jest w rękach pomniejszych akcjonariuszy. Zyski kontrolowanego przez państwo holdingu OMV sięgają 2,5 mld euro przy rocznym obrocie firmy $34 \mathrm{mld}^{15}$.

Na rynku niemieckim bardzo ważna była dla OMV działania mające na celu wzmocnienie pozycji w południowo niemieckim Bayeroil. OMV kupił Bayernoil od BP w 2003 roku za 377 mln euro. Niemiecka firma była szczególnie ważna dla OMV ze względu na posiadane rurociagi i możliwość korzystania z liczącego ponad 700 km Transalpine Ölleitung, naftociągu z Triestu do Ingolstad i austriackiego Neustadt, z możliwością

${ }_{13}$ M. Paszyn.Kooperacja austriackich firm energetycznych w pierwszej dekadzie XXI wieku. [w:] Polityka - kultura - społeczeństwo. Niemcy, Austria, Szwajcaria w pierwszej dekadzie XXI wieku.Red E. Kuczyński, M. Tomczyk, Łódź 2013, s. 135-136.

${ }^{14}$ Ibidem. Po kolejnym rozszerzeniu UE w 2004, OMV kupił 51\% rumuńskiej firmy petrochemicznej Petrom. Inwestycja ta byłą największą dotychczasową operacją finansową koncernu.W roku 2006, OMV kupił 34\% udziałów w tureckiej firmie naftowej Petrol Ofisi.M.

${ }^{15}$ M. Paszyn. Aktywność biznesowa i inwestycyjna koncernu OMV w pierwszej dekadzie XXI wieku, [w:] Między historią a literaturą. Księga Jubileuszowa dedykowana prof. Krzysztofowi A. Kuczyńskiemu, pod red. J. Ciesielska-Klikowska, A. Kisztelińska-Węgrzyńska, Łódź 2013. 
dotarcia do Bratysławy i korzystania z europejskiego systemu naftociągów Pan-European Oil Pipeline.

13.grudnia 2013 konsorcjum firm Carlyle - Vitol Group oglosiło zakup 45\% udziałów w rafinerii w Niemczech od OMV Bayernoil ${ }^{16}$. Powodem takiej decyzji biznesowej było z jednej strony strategia Carlyle Vitol Group mająca na celu wzmocnienie pozycji na niemieckim rynku przetwarzania, dystrybucji i magazynowania ropy i jej pochodnych. Powodem jest także chęć wzmocnienia sojej pozycji biznesowej w północno-zachodniej Europie. Carlyle to powstała w 1987 firma private equity z siedzibą w Waszyngtonie, osiągająca obrót rzędu 170 mld \$ i zysk netto 2 mld \$ rocznie $^{17}$. Z kolei firma Vitol to zarejestrowana w Szwajcarii firma międzynarodowa założóna przez Henka Vietora w 1966, zajmująca się handlem ropa, metalami, węglem i gazem, uzyskała w 2012 ponad 300 mld dolarów obrotów ${ }^{18}$. Obie firmy będą posiadać po $50 \%$ w Varo Energii, firmie zależnej Bayernoil, która obejmuje przedsięwzięcia rafineryjne, dystrybucji hurtowej i detalicznej paliwa.

Dla analityków rynku energetycznego zastanawiajacy był fakt, że OMV zdecydował się sprzedać nie tylko udziały w Bayernoil, ale i fabrykę bitumiczną w Grossmehring, inwestycja ta mocno usadawiała OMV na rynku usług petrochemicznych. Jednak już sam fakt zatrudniania w styczniu 2012 Deutsche Bank w obsłudze program zmiany portfolio firmy, był znakiem, że austriacka firma koncentruje się na wydobyciu surowca i produkcji tylko paliw. Natomiast dla Carlyle i Vitol, ważne było to, że zyskują dostęp niemieckiego rynku paliwowego.

Według doniesień agencji Blomberg wartość transakcji wyniosła 400 mln euro do 600 mln euro. Tego typu działania OMV wpisują się w pewnien trend biznesowy. W dniu 18.11.2011, ORLEN Deutschland $\mathrm{GmbH}$ oraz OMV Deutschland GmbH podpisały umowę o zakupie przez ORLEN 56 stacji benzynowych sieci OMV zlokalizowanych w Turyngii i Saksonii. Tym samym niemiecka spółka z Grupy ORLEN weszła na rynki kolejnych krajów związkowych. Po transakcji sieć ORLEN Deutschland będzie liczyła 574 stacje paliw ${ }^{19}$. Cytowani przez agencję analitycy potwierdzają opinię, że działania te, sprzedaż udziału $\mathrm{w}$ rafineriach, czy sieci stacji benzynowych, wynikają ze strategii OMV oraz zaangażowania koncernu w wielkie

${ }_{16}$ OMV to sell 45\% stake in Germany's Bayernoil refinery to Carlyle, Vitol By JONATHAN TIRONE.

17 The Wall Street Journal: The Carlyle Group and Vitol Group to invest in Varo Energy to Create a Major New Energy Midstream Group across North-West Europe, 19.12.2013.

18 Ibidem.

19 Orlen Deutschland kupił 56 stacji w Niemczech od OMV, ma już 574 szt, Gazeta Wyborcza, 19.11.2010, Orlen przejmuje niemieckie stacje OMV, www.cire.pl, 19.11. 2010. 
przedsięwzięcia biznesowe związane z przesyłem gazu z Azji Środkowej. Jest to ważna $\mathrm{z}$ punktu widzenia UE, bliskowschodnia inwestycja OMV związana z budową gazociągu Nabucco, łączącego pola gazowe nad Morzem Kaspijskim z Europą Południową. W roku 2009 OMV i szereg innych austriackich firm rozpoczęło pracę nad realizacją wartego $4.6 \mathrm{mi}$ liarda euro, i liczącego 3,300 km długości gazociągu Nabucco, który miało uniezależnić częściowo Europę od rosyjskiego gazu. Projekt zakładał transport kaspijskiego i irańskiego gazu na Bałkany i Węgry. Docelowo $\mathrm{w}$ austriackim Baumgarten, ma powstać przepompowania gazu, sprzedawanego dalej do Europy Zachodniej ${ }^{20}$. W 2009 akces złożyło niemieckie RWE. W lipcu 2009, OMV zadeklarowało, że doradcą konsorcjum budującego Nabucco został Joschka Fischer. Świadczyć to miało o wadze projektu dla zachodnioeuropejskich kontrahentów. Ponadto w roku 2010 RWE zadeklarowało zainwestowanie ponad 7 mld dolarów w budowę Nabucco. Podobnie jak OMV podpisało umowy zarówno z irańskim National Oil Company, jak i z rządem irackiego Kurdystanu, odnośnie współpracy przy budowie i eksploatacji gazociągu. Bez aktywnego udziału OMV, zapewne niemiecki RWE nie byłby skory do tego typu inwestycji i deklaracji biznesowych ${ }^{21}$. Jak powszechnie wiadomo projekt Nabucco napotykał i nadal napotyka na rozliczne trudności. Agencja Reuters poinformowała 3 grudnia 2012, że niemieckie RWE zamierza wycofać się z europejskiego projektu Nabucco-West i sprzedać swoje udziały w wysokości 16,1 procent OMV. Odpowiednia umowa miała zostać podpisana jeszcze przed końcem roku. Eksperci wskazuja, że gazociąg Nabucco to projekt stojący pod znakiem zapytania. Firmy są rozczarowane szacunkami rosnących kosztów i możliwą nadprzepustowością rury²2.

Przykładem, że relacje biznesowe firm austriackich i niemieckich nie zawsze układają się w sposób łatwy, przewidywalny, może być funkcjo-

${ }^{20}$ Po zakończeniu budowy gazociąg ma przesyłać 65 mld m sześc. gazu do Europy. Firmą wiodącą w realizacji budowy i eksploatacji gazociągu jest OMV. Konsorcjum to „narzuciło" innym uczestnikom przedsięwzięcia Baumgarten, jako kluczowe miejsce rozdziału przesyłu. Obok OMV w przedsięwzięcie zaangażowane są: Botas z Turcji, Bulgargaz, rumuński Transgaz oraz węgierski MOL akces złożyło niemieckie RWE. Warto pamiętać, że pomimo ostatnich, zawirowań przy realizacji projektu budowy Nabucco Gas Pipeline związanych z konfliktem na linii Gazprom - OMV, dotyczącym sposobu zaangażowania się węgierskiego MOL - a w konkurencyjny projekt South Stream, projekt ten jest realizowany. Spór pomiędzy Gazpromem a OMV, dwoma firmami będącymi akcjonariuszami węgierskiej firmy, został załagodzony porozumienie zawartym w listopadzie 2011. Nadal, obok OMV, znaczącą rolę, przy budowie Nabucco odgrywają firmy z Turcji, Rumuni i Węgier czyli krajów gdzie OMV ma swoje wpływy jako znaczący akcjonariusz odpowiednio Petrol Ofisi, Petromu i MOL.

${ }^{21}$ V. Eckert, RWE signs Nabucco cooperation deal with Iraq Kurds, 27.8.2010.

22 Ibidem 
nowanie drugiego co do wielkości producenta energii w Austrii. EVN Group (Energieversorgung Niederösterreich), funkcjonujący w Dolnej Austrii, który dostarcza energię do odbiorców w Austrii i w sąsiednich krajach. Siedziba firmy umiejscowiona jest w malej miejscowości Maria Enzersdorf. Firma zatrudnia 8 tysięcy ludzi, a jej obrót w 2011 wyniósł 2,7 mld euro. EVN w latach osiemdziesiątych znalazł się na giełdzie, z zastrzeżeniem, że 51 procent akcji przejmuje rząd Dolnej Austrii. Natomiast w latach 1989 i 1990 pozostałe 49\% udziałów znalazło się w wolnym obrocie. Pozyskane w ten sposób środki pozwoliły na szereg inwestycji w kraju przykładem może być rozwinięcie inwestycji w zakresie wodociągów i telekomunikacji lokalnej ${ }^{23}$. Głównym surowcem wykorzystywanym przez EVN jest energia wodna, geotermalna i wiatrowa. Głównymi udziałowcami EVN Group jest rząd Dolnej Austrii posiadający 51\%, kolejnym akcjonariuszem jest niemiecka EnBW posiadająca 35\% akcji. Pozostałe 14\% jest $\mathrm{w}$ rękach mniejszościowych akcjonariuszy. Gdy EVN zdecydowało na wzmocnienie roli państwa i drobnych akcjonariuszy kosztem drugiego dużego udziałowca, wobec oporu niemieckiej firmy zdecydowano o podwyższenia kapitału, na wypadek, że EnBW, nie zgodzi się sprzedać sprzedać części akcji w ramach transakcji. Energie Baden - Wirttemberg poinformował, że nie zatwierdzi takiej formuły sprzedaży. Początkowo EVN planował sprzedać ogółem 57.300.000 akcji celem podwyższeniu kapitału, obejmujący 16.400 .000 akcji nowych akcji oraz 40.900 .000 z dotychczasowego udziału w kapitale EnBW. Niemiecka firma, po tej transakcji zmniejszyłaby swój udział zatem postrzegać swój udział z 35,72 proc do 10 proc. Jednak opór EnBW, która zdecydowała się nie sprzedawać swoich akcji opóźnił te transakcję. EnBW uważał, że proponowana cena 10,50 euro za akcję jest zbyt niska. Pomimo oporu niemieckiego inwestora zdecydowano o emisji akcji $w$ tej cenie. Prezes EVN Burkhard Hofer wyraził "ubolewanie” z powodu decyzji niemieckiego partnera i powiedział, że austriacka grupa ponownie wyemituje nowe akcje. Takie działanie może jeszcze bardziej zmniejszyć udziały niemieckiej EnBW w EVN. Jednak władze austriackiej spółki są przekonane, że kondycja finansowa firmy pozwoli na pozyskanie odpowiedniej liczby inwestorów ${ }^{24}$.

Czynnikiem dodatkowo sprzyjającym rozwojowi nowych projektow współpracy energetycznej, była decyzja podjęta na szczeblu UE o zwiększeniu zaangażowania finansowego $\mathrm{w}$ tworzenie nowych interkonektorow. Oprócz istniejącego instrumentu wsparcia TEN-E (Trans-European Networks for Energy) stworzony został w 2009 r. nowy plan inwestycyjny

${ }^{23}$ M. Paszyn, Austriacka kooperacja..., s. 134.

${ }^{24}$ Austrian power group EVN presses ahead with capital increas, Expatica, 21.10. 2010. 
- EEPR (European Energy Programme for Recovery), przewidujący zainwestowanie ponad 2,3 mld euro w projekty połączeń międzysystemowych $\mathrm{w}$ sektorze gazu i energii elektrycznej. Jest to pierwszy przypadek przeznaczenia $\mathrm{z}$ budżetu UE tak znacznych środków na projekty w obszarze energetyki ${ }^{25}$. W tym celu KE wskazała jako konieczne stworzenie łączników systemowych głownie na terytorium Niemiec aby połączyć nowe północne moce wytwórcze z elektrowniami szczytowo - pompowymi, które mają powstać w Austrii i Szwajcarii oraz z nowymi mocami wytwórczymi krajów południowo-wschodnich. Zwiększona ma zostać również przepustowość między Słowacją i Węgrami oraz Austrią. Wypracowaniem konkretnych propozycji i planów regionalnych ma się zająć powołana przez władze UE Grupa Wysokiego Szczebla (HLG - High Level Group), w skład której wchodzą kraje Europy Środkowej i Wschodniej (Czechy, Polska, Słowacja, Węgry, oraz Austria, Bułgaria, Niemcy, Rumunia). Grupa zajmować ma się wzmacnianiem regionalnej współpracy krajów regionu i opracowywaniem planów rozwoju połączeń międzysystemowych gazu, ropy, energii elektrycznej.

Dzieje się tak pomimo, że Austriacka Izba Energii przedstawiła w listopadzie 2013 stanowisko, w którym domaga się reformy rynku energii w Niemczech. Zdaniem austriackich producentów energii zbyt szybki rozwój odnawialnych źródeł energii (OZE) w Niemczech doprowadził do destabilizacji rynku energii w obu krajach. Dlatego austriacki sektor energetyczny postuluje ujednolicenie systemu wsparcia dla OZE w Niemczech i w Austrii oraz zbudowanie wspólnego rynku mocy (systemu elektrowni zapewniających moce rezerwowe dla rynków energii obu państw). Austriacy proponują ograniczenie przywilejów dla OZE, m.in. poprzez rezygnację $z$ pierwszeństwa $w$ ich dostępie do sieci i skłonienie producentów prądu z OZE do sprzedaży energii bezpośrednio na rynku, zamiast sprzedawania jej operatorom sieci po gwarantowanej przez niemieckie państwo cenie ${ }^{26}$.Szybki rozwój energetyki wiatrowej i słonecznej w Niemczech doprowadził do nierównowagi na rynku niemieckim i austriackim - subsydiowana energia ze źródeł odnawialnych jest sprzedawana po niższych cenach niż ta z elektrowni konwencjonalnych.

Należy jednak pamiętać, ze pomimo austriackich obaw także niemiecki przemysł i odbiorcy indywidualni są zależni od południowego sąsiada. Jeden $z$ dostawców energii w Niemczech był zmuszony użyć rezerw z austriackich elektrowni w ciągu dwóch dni w grudniu 2011 jako

${ }^{25}$ K. Pronińska, Wptyw wspotpracy energetycznej krajow Europy Środkowej na regionalne bezpieczeństwo energetyczne i politykę energetyczna, wyd. Centrum Europejskie Natolin, "Zeszyty CEN" nr 51, Warszawa 2013.

${ }^{26}$ R. Bajczuk, Austriacy apeluja o reforme rynku energii w Niemczech, Analizy OSW, 27.11. 2013. 
„środek zapobiegawczy”27. Według gazety Die Welt, operator sieci Tennet, czyli część niemieckiej krajowej sieci energetycznej, został zmuszony, by wykorzystać energię z Austrii dnia 8 i 9 grudnia 2011 roku, aby zagwarantować stabilność jej podaży. Powstały w 1998 Tennet jest operatorem energetycznym należącym do holenderskiego Ministerstwa Gospodarki. Od 1.1.2010, Tennet jest właścicielem niemieckiej firmy przesyłowej Transpower Stromübertragungs $\mathrm{GmbH}$, która przed transakcją była częścią koncernu E.ON. Od tej pory znany jest na rynku jako Tennet TSO GmbH. Firma Tennet obecnie ma do dyspozycji 20392 kilometrów sieci, którymi w prąd zaopatruje 36 milionów odbiorców. Jej roczny obrót wynosi ponad 1,5 miliarda euro. Zatrudnia 2000 ludzi. Transakcja została potwierdzona przez Federalna Agencję Przesyłu Sieciowego. Austriacka firma EVN na krótko uruchomiła starą elektrownię w pobliżu Grazu, aby wyeksportować energię do Niemiec. Rzeczniczka TenneT powiedziała gazecie die Welt, warunki pogodowe w północnych Niemczech nie pozwoliły na pełne wykorzystanie możliwości elektrowni wiatrowych nad Morzem Północnym, dlatego tez południowa część Niemiec musiała być zaopatrywana przez austriackich system energetyczny. Ponadto $w$ wyniku decyzji rządu w Berlinie o rezygnacji z energetyki jądrowej zamknięto, w tym czasie elektrownię jądrową Gundremmingen w Bawarii, a czasowo uruchomione stare elektrownie węglowe na nadążały z dostarczeniem prądu do odbiorców. Sieć energetyczna TenneT obsługuje centralny obszar Niemiec od duńskiej granicy na północy, przez Bawarię aż po Alpy na południu. Niezwykłe długi i wąski kształt strefy TenneT, przebiegający przez najbardziej uprzemysłowione tereny Niemiec, oznacza, że jest on szczególnie podatny na awarie i ograniczenie "wąskich gardeł" transportu energii elektrycznej z północy na południe. Wydarzenie to spowodowało dyskusję o przyszłości energetyki w Niemczech i kooperacji z firmami austriackimi. „Przez najbliższe 50 lat Niemcy będą zdane na dostawy energii elektrycznej z Austrii - twierdzi Michael Fuchs - szef Tennet ${ }^{28}$. I to wcale nie chodzi o techniczne energetyczne wsparcie lecz o symbiozę - mówi Fuchs. Bez austriackiego prądu niemiecka rewolucja w energetyce jest niemożliwa - dodaje. Prezes Tennet stwierdził, ze klasyczne elektrownie po wyłączeniu reaktorów atomowych, nie były w stanie wytworzyć wystarczającej ilości energii, a dostawy z ekoelektrowni (wiatraki, solary) były niestabilne ze względu na zmienną aurę. W opinii Fuchsa, ekonergetyka nie dysponuje jeszcze wystarczająca ilością odpowiednich sieci przesyłowych. Posiadane obecne $2000 \mathrm{~km}$ sieci to za mało. Potrzebne jest więc dodatkowe $3800 \mathrm{~km}$. Koszt ich budowy szacuje się na 20 miliardów euro,

${ }_{27}$ Germany forced to buy Austrian electricity, www. thelocal.de, Published: 05 Jan 2012.

28 Ebe.org.pl, M. Wieroński, Energetyczny Anschluss...Niemiec, 10.09.2012. 
więc nie powstaną natychmiast, lecz w ciągu najbliższych 10 lat $^{29}$.

Jak widzimy na tym mało nagłośnionym przykładzie, decyzja o zamykaniu elektrowni jądrowych i oparciu energetyki niemieckiej o gaz i odnawialne źródła energii, niekiedy przynosi nieoczekiwane problemy. Niemcy nie mają 100 procentowego zabezpieczenia swojego rynku energetycznego, pomimo produkcji 558 miliardów kWh energii rocznie, dlatego też zmuszone są korzystać z potencjału energetycznego południowego sąsiada, który produkuje $68 \mathrm{mld} \mathrm{kWh}$ energii ${ }^{30}$. Powstaje pytanie jak to się dzieje, że firmy energetyczne z Austrii są w stanie wesprzeć swych kontrahentów z większego kraju, produkującego znacznie większą ilość energii eksportując ponad 16 mld kWh energii? Wynika to z kilku elementów. Austria jest w światowej czołówce technologii i usług związanych z produkcją energii. $Z$ racji położenia geograficznego i ukształtowania terenu jest wielki producentem energii z elektrowni wodnych, najtańszego źródła energii odnawialnej. Austria opracowała również technologie i rozwiązania przydatne $w$ rozwijaniu energetyki opartej o elektrownie wodne i wiatrowe, wyprzedzając inne kraje UE. Udział odnawialnych źródeł energii jako procent całkowitego zużycia energii jest tradycyjnie wyższe niż w innych krajach UE. Od początku lat osiemdziesiątych, kiedy to produkcja energii ze źródeł odnawialnych przekroczyła poziom 20 procent, a ma wzrosnąc do 85 procent w roku 2020. Oznacza to Austria jest liderem w Europie, jeśli chodzi o produkcję tego rodzaju energii. Dzięki temu Austria będzie niezależna od importowanej energii elektrycznej z energii atomowej czy węglowej. Dzięki podwojeniu finansowania nowych technologii w Austrii powstają miliardowe inwestycje w "zielone technologie". Obecnie w Austrii eko-przemysł generuje roczne przychody w wysokości 10,6 mld EUR i zatrudnia około 87.000 osób ${ }^{31}$. Jak można się domyślać możliwości rozwoju tego sektora będą coraz większe, zważywszy na fakt, że działania energetyczne UE zmierzają do zwiększenia udziału OZE w produkcji energii.

Jednak należy pamiętać, ze zarówno Niemcy jak i Austria są ograniczeni w swoich relacjach energetycznych funkcjonowaniem europejskiego rynku energii. Operatorzy systemów przesyłowych Czech, Polski, Słowacji i Węgier przygotowali wspólnie raport analizujący zjawisko przepływów nieplanowych w systemach elektroenergetycznych Europy Środkowo-Wschodniej ${ }^{32}$. Przeprowadzona analiza udowadnia, że handlo-

\footnotetext{
${ }^{29}$ Ibidem.

30 Energy policies..., s. 116.

31 Ibidem, s. 56.

${ }^{32}$ Rynekinfrastruktury.pl, Energia z Niemiec zagraża bezpieczeństwu energetycznemu Polski.
} 
wa wymiana transgraniczna pomiędzy Niemcami i Austrią, realizowana w ramach wspólnego obszaru rynkowego DE-AT, powoduje znaczące rzeczywiste przepływy mocy przez sąsiednie systemy elektroenergetyczne. $Z$ raportu wynika, że zmiana obecnych zasad rynkowych w zakresie organizacji handlowej wymiany transgranicznej $w$ regionie CEE jest konieczna, w szczególności w zakresie rozdzielenia wspólnego obszaru rynkowego Niemcy-Austria i wprowadzenia obowiązku koordynacji alokacji zdolności przesyłowych na tej granicy. wraz ze wzrostem poziomu wymiany handlowej DE-AT, kraje sąsiednie, a przede wszystkim Polska i Czechy, muszą borykać się ze znaczącymi przepływami nieplanowymi, zagrażającymi bezpieczeństwu pracy systemu przesyłowego ${ }^{33}$.

Podane przykłady współpracy biznesowo-inwestycyjnej firm energetycznych z Austrii i Niemiec pokazuja jak bardzo, poszczególne państwa UE związane są gospodarczo ze swoimi sąsiadami, a ta współpraca, nie zawsze łatwa, pozwala na zacieśnianie związków gospodarczych, w których nie zawsze silniejszy i większy kontrahent ma głos decydujący. Przykłady austriackich kooperacji energetycznych, inwestycji na trudnym, choć bogatym niemieckim rynku pokazuja że mniejszy partner, odpowiednio zaangażowany w przedsięwzięcie biznesowe może osiągnąć swoje cele. Tego typu kooperacje zapewne będą wzmacniać rolę austriackich koncernów na rynku niemieckim, o ile niemiecki rynek zostanie w pełni zliberalizowany, a prąd pochodzący z odnawialnych źródeł energii, nie będzie dotowany przez władze federalne. Jest to o tyle ważne, że w Niemczech trwa weryfikacja realizacji nowej strategii energetycznej, przyjętej latem 2011 roku. Kręgi gospodarcze i eksperci biją na alarm. Szybkie tempo przestawienia gospodarki niemieckiej na odnawialne źródła energii okazuje się zadaniem niezwykle trudnym i kosztownym. Realizacja kluczowych założeń nowej strategii, takich jak rozbudowa sieci przesyłowych i budowa nowych elektrowni konwencjonalnych napotyka coraz większe trudności natury ekonomicznej i prawnej. Problemy stwarza również rozwój sektora zielonych technologii. Obecnie szansę realizacji mają jedynie te założenia strategii, które są ekonomicznie uzasadnione z punktu widzenia inwestorów bądź mają odpowiednie finansowe wsparcie ze strony państwa. Zagrożeniem dla powodzenia strategii są także brak całościowej koordynacji jej realizacji oraz obciążenia finansowe społeczeństwa i gospodarki ${ }^{34}$. W najbliższym czasie niemiecki rząd będzie dążył nie tylko do korekty wewnętrznych regulacji, które umożliwią urzeczywistnienie transformacji energetyczne. Dlatego tez współpraca niemieckich i austriackich

${ }^{33}$ Ibidem.

${ }^{34}$ K. Mazur, Kosztowna rewolucja energetyczna w Niemczech. Opóźnia się realizacja Energiewende, Komentarze OSW, 5.10. 2010. 
koncernów energetycznych może być coraz częstsza i obejmować nowe segmenty rynku energetycznego. Wówczas firmy austriackie posiadające technologie i doświadczenie w pozyskiwaniu energii $\mathrm{z}$ odnawialnych źródeł energii mogą być idealnym partnerem dla niemieckich koncernów energetycznych.

\section{Zusammenfassung}

\section{GESCHÄFTSBEZIEHUNGEN ENERGIEUNTERNEHMEN AUS DEUTSCHLAND UND ÖSTERREICH WÄHREND DER FINANZKRISE VON 2008 BIS 2013 JAHREN}

Dieser Artikel stellt die Wechselwirkungsenergie-Unternehmen aus Deutschland und Österreich in der Finanzkrise. Dazu gehören Unternehmen wie Verbund AG, EVN und OMV. Österreichischen Energieunternehmen in Deutschland sind wichtige Akteure in der lokalen Energiemarkt. Dadurch, dass die entsprechende Technologie- und Business-Erfahrung, können diese Unternehmen mit den deutschen Riesen, wie E.ON kooperieren Ein Beispiel ist der Bau von Wasserkraft in Bayern. Im Gegenzug Ölkonzern OMV Partnerschaft mit RWE in den Bau von Gasleitungen. Zunächst wird der Bau der Nabucco-Gas-Pipeline, ist derzeit in den Bau der South-Stream-Pipeline. 